\title{
Liver function tests in patients of pre-eclampsia in Bhilai, Chhattisgarh, India: a clinical study
}

\author{
Rashid Lodhi, Navanil Roy*
}

Department of Biochemistry, Shri Shankracharya Institute of Medical Sciences, Junwani Bhilai, Chhattisgarh, India

Received: 09 October 2018

Accepted: 13 November 2018

*Correspondence:

Dr. Navanil Roy,

E-mail: navnil2013@gmail.com

Copyright: (C) the author(s), publisher and licensee Medip Academy. This is an open-access article distributed under the terms of the Creative Commons Attribution Non-Commercial License, which permits unrestricted non-commercial use, distribution, and reproduction in any medium, provided the original work is properly cited.

\begin{abstract}
Background: Pre-eclampsia is a multisystem disorder, which occurs only in pregnant women during the second and third trimesters of pregnancy and is associated with raised blood pressure and proteinuria. Liver function Test (LFT) abnormalities occur in $3 \%$ of the pregnancies and probably the lesion that causes elevated serum liver enzymes. This study was conducted to compare the liver function tests in pre-eclampsia with normal pregnancy.

Methods: This study was carried out on 60 pregnant women after 20 weeks of gestation admitted in Obstetrics and Gynaecology units of Shri Shankaracharya Institute of Medical Sciences, Bhilai, and Chhattisgarh. The subjects were divided into two groups. Group A comprised of 30 cases of pre-eclampsia having blood pressure $\geq 140 / 90 \mathrm{~mm} \mathrm{Hg}$, proteinuria in 24 hours $\geq 300 \mathrm{mg}$ and edema. Group B had 30 normal pregnant women after 20 weeks of gestation. The data including parity, period of gestation, blood pressure and presenting complaints of all subjects were recorded. Serum bilirubin, total protein, albumin and plasma levels of liver enzymes ALT and AST were measured.

Results: The mean value of serum bilirubin in cases was 3.45 and in controls it was 0.50 . The mean value of enzymes ALT in cases was 92.7 while in the controls it was 22.37. Mean serum AST in the cases was 85.43 and in the controls, it was 21.96. Total protein in cases was 7.77 and controls it was 7.26. Albumin level in cases was 4.62 and controls were 4.17 .

Conclusions: Increased concentrations of serum bilirubin, total protein, albumin and liver enzymes ALT, AST were found in pre-eclampsia cases.
\end{abstract}

Keywords: Hypertension, Liver function Test (LFT), Morbidity, Pre-eclampsia, Pregnancy, Women

\section{INTRODUCTION}

Liver is a very vital organ of our body accompanied with multiple functions in our body. Hypertension is the most common medical disorders in pregnancy. ${ }^{1}$ Abnormal liver function test (LFT) occurs in $20 \%$ to $30 \%$ of pregnancies complicated by Pre-eclampsia and are associated with poor maternal and fetal outcomes. ${ }^{2,3}$ Pre-eclampsia and eclampsia are pregnancy induced hypertensive disease. ${ }^{4}$ Pregnancy Induce Hypertension (PIH) is raised blood pressure without proteinuria during the second half of pregnancy. Pre-eclampsia is a multisystem disorder, unique to pregnancy that is usually associated with raised blood pressure and proteinuria after 20 weeks of gestation. Eclampsia is one or more convulsions in association with syndrome of pre-eclampsia., ${ }^{5,6}$ In preeclampsia the systolic BP is $\geq 140 \mathrm{~mm} \mathrm{Hg}$ and diastolic $\mathrm{BP} \geq 90 \mathrm{~mm} \mathrm{Hg}$ in a woman with previously normal blood pressure and with proteinuria $\geq 0.3 \mathrm{~g}$ in a 24 hour urine collection. ${ }^{5}$ The main cause of pre-eclampsia is vasoconstriction and thickening of vascular media which decreases vascular capacity and increases peripheral resistance. The factors that appear to have role include placenta, maternal immune response, maternal vascular disease, genetic predisposition and maternal low calcium level. The cellular cause of pre-eclampsia lies within the 
placenta and resolution of pre-eclampsia starts with removal of placenta at delivery. In pre-eclampsia the ratio of prostacycline-thromboxane production rate is decreased favoring the vasoconstrictive thromboxane. During preeclamptic pregnancy, the placenta is under oxidative stress with increased production of lipid peroxides and decreased production of antioxidants. Maternal circulating oxidized lipids may be the cause of endothelial cell activation. ${ }^{7}$

Liver function test (LFT) abnormalities occur in $3 \%$ of the pregnancies and pre-eclampsia is the most frequent cause. In the last trimester liver disease associated with abnormal liver function tests, nausea and/or vomiting and abdominal pain is due to severe pre-eclampsia, HELLP syndrome or acute fatty liver of pregnancy with or without sub-capsular hepatic hematomas, amongst which there is an ovelap. ${ }^{8}$

Liver dysfunction during pre-eclampsia has serious consequences. In pre- eclampsia accompanied by HELLP syndrome, an elevation in liver function test result is noted. Alanine aminotransferase (ALT) and Aspartate aminofransferase (AST) may also be elevated and hyperbilirubinemia may occur, especially in the presence of haemolysis. Periportal hemorrhagic necrosis in the periphery of the liver lobule is probably the lesion that causes elevated serum liver enzyme levels. Haemorrhage under the liver capsule can be so severe that the capsule ruptures and causes life threatening intra peritoneal bleeding. ${ }^{8}$ The objective of this study was to compare liver function tests in pre-eclampsia and normal pregnancy.

\section{METHODS}

This study was carried out on 60 pregnant women after 20 weeks of gestation admitted in Obstetrics and Gynaecology units of Shri Shankaracharya Institute of Medical Sciences, Bhilai, Chhattisgarh from July 2017 to July 2018 with convenience sampling. The subjects were divided into two groups. Group A comprised of 30 cases of pre-eclampsia having blood pressure $\geq 140 / 90 \mathrm{~mm} \mathrm{Hg}$, proteinuria in 24 hours $\geq 300 \mathrm{mg}$ and edema. Group B had 30 normal pregnant women after 20 weeks of gestation. The data including parity, period of gestation, blood pressure and presenting complaints of all subjects were recorded. Serum bilirubin, total protein, albumin and plasma levels of liver enzymes ALT and AST were measured.

\section{Inclusion criteria}

- Both the cases and controls were in the age group 15-45 years.

\section{Exclusion criteria}

- Those with a major systemic disease which may elevate the patient's blood pressure, or which may change the liver function tests eg renal diseases, liver diseases, diabetes and cardiac disease were excluded.

- Patients using any drugs that affect liver function were not included.

Verbal and written consent was obtained from each subject. Complete obstetrical and family history was recorded on proforma designed for the study.

\section{Statistical analysis}

Four variables were measured for all cases and controls i.e. Serum bilirubin level, total protein, albumin and plasma levels of liver enzymes ALT, AST were measured using auto quant Meril 200 analyzer. Mean and standard deviation were calculated. The data were calculated. The data were analyzed using SPSS-16. The mean values were compared between cases and controls using t-test at $5 \%$ level of significance.

\section{RESULTS}

The mean value of serum bilirubin in cases was 3.45 and in controls it was 0.50 . The mean value of enzymes ALT in cases was 92.7 while in the controls it was 22.37. Mean serum AST in the cases was 85.43 and, in the controls, it was 21.96. Total protein in cases was 7.77 and controls it was 7.26. Albumin level in cases was 4.62 and controls were 4.17 .

Table 1: LFT.

\begin{tabular}{|c|c|c|c|c|}
\hline & $\begin{array}{l}\text { Control } \\
\text { mean } \\
\text { (SD) }\end{array}$ & $\begin{array}{l}\text { Cases } \\
\text { mean } \\
(\mathrm{SD})\end{array}$ & t-statistic & p-value \\
\hline Age & $\begin{array}{l}29.23 \\
(6.08)\end{array}$ & $\begin{array}{l}27.53 \\
(5.15)\end{array}$ & 1.16 & 0.24 \\
\hline $\begin{array}{l}\text { Total } \\
\text { bilirubin }\end{array}$ & $\begin{array}{l}0.503 \\
(0.19)\end{array}$ & $\begin{array}{l}3.45 \\
(0.78)\end{array}$ & -20.02 & $0.00001 *$ \\
\hline $\begin{array}{l}\text { Direct } \\
\text { bilirubin }\end{array}$ & $\begin{array}{l}0.282 \\
(0.05)\end{array}$ & $\begin{array}{l}1.58 \\
(0.34)\end{array}$ & -20.66 & $0.00001 *$ \\
\hline $\begin{array}{l}\text { Indirect } \\
\text { bilirubin }\end{array}$ & $\begin{array}{l}0.302 \\
(0.09)\end{array}$ & $\begin{array}{l}4.02 \\
(1.68)\end{array}$ & -12.06 & $0.00001 *$ \\
\hline SGPT & $\begin{array}{l}22.37 \\
(6.97)\end{array}$ & $\begin{array}{l}92.7 \\
(19.91)\end{array}$ & -18.25 & $0.00001 *$ \\
\hline SGOT & $\begin{array}{l}21.96 \\
(5.43)\end{array}$ & $\begin{array}{l}85.43 \\
(13.65)\end{array}$ & -23.64 & $0.00001 *$ \\
\hline $\mathrm{TP}$ & $\begin{array}{l}7.26 \\
(0.65)\end{array}$ & $\begin{array}{l}7.77 \\
(0.91)\end{array}$ & -2.44 & $0.01785^{*}$ \\
\hline Albumin & $\begin{array}{l}4.17 \\
(0.4)\end{array}$ & $\begin{array}{l}4.62 \\
(0.95)\end{array}$ & -2.37 & $0.02251 *$ \\
\hline Globumin & $\begin{array}{l}2.77 \\
(0.46)\end{array}$ & $\begin{array}{l}3.12 \\
(0.73)\end{array}$ & -2.22 & $0.0308 *$ \\
\hline
\end{tabular}

The LFT variables were noted on cases as well as control. All the variables are continuous in nature. t-test for two independent samples has been applied to data as the samples are independent. 
It has been observed that cases and controls were matched for age and there was no significant difference found in age of cases and control.

Table 2: RFT.

\begin{tabular}{|c|c|c|c|c|}
\hline & $\begin{array}{l}\text { Control } \\
\text { mean } \\
(\mathrm{SD})\end{array}$ & $\begin{array}{l}\text { Cases } \\
\text { mean } \\
(\mathrm{SD})\end{array}$ & t-statistic & p-value \\
\hline Urea & $\begin{array}{l}24.5 \\
(6.01)\end{array}$ & $\begin{array}{l}43.76 \\
(6.03)\end{array}$ & -12.38 & $0.00001 *$ \\
\hline Creatinine & $\begin{array}{l}0.80 \\
(0.09)\end{array}$ & $\begin{array}{l}1.51 \\
(0.18)\end{array}$ & -18.62 & $0.00001 *$ \\
\hline Uric Acid & $\begin{array}{l}4.45 \\
(1.09)\end{array}$ & $\begin{array}{l}5.41 \\
(0.84)\end{array}$ & -3.8 & $0.00035 *$ \\
\hline
\end{tabular}

*Statistically significant

Total bilirubin levels were found to be higher in cases compared to control. The difference of total bilirubin turned out to be highly significant statistically.

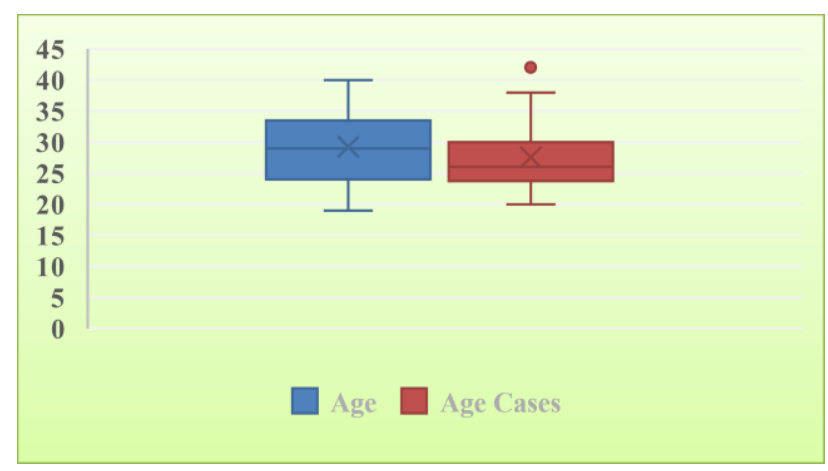

Figure 1: Box and Whisker plot for age distribution.

Direct bilirubin readings show that the levels were elevated in cases and the difference between levels of direct bilirubin among cases and controls turned out to be highly significant.

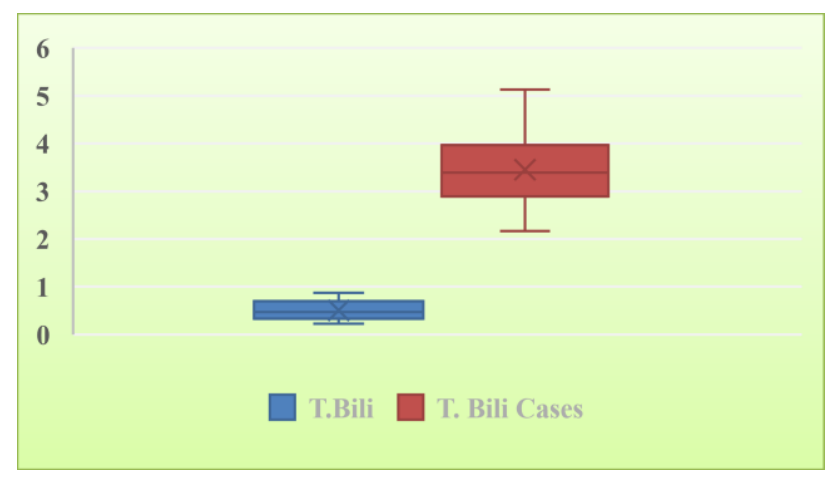

Figure 2: Box and Whisker plot for total bilirubin among control and cases.

Indirect bilirubin was found to be significant and the readings were observed to be higher in cases. SGPT and SGOT were found to be very high in cases and the difference was statistically highly significant.

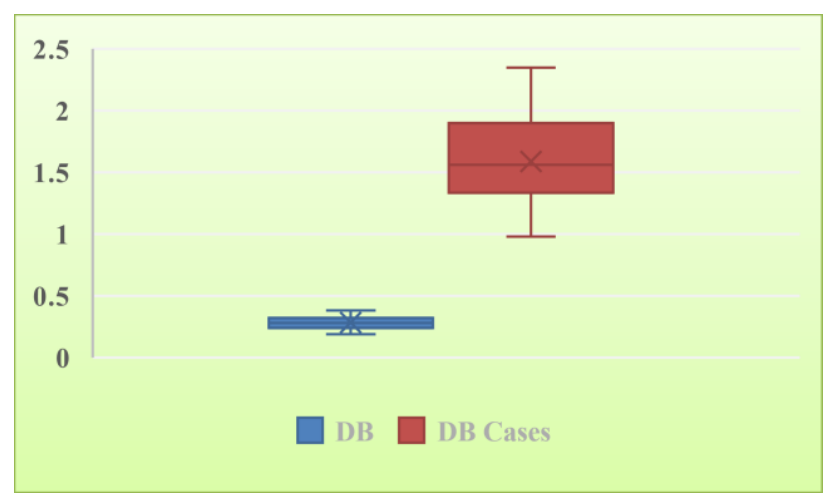

Figure 3: Box and Whisker plot for direct bilirubin among control and cases.

TP levels were slightly elevated in cases and the difference was statistically significant. In case of albumin and globulin the observations were recorded higher in cases compared to control. Albumin and globulin were found to significant.

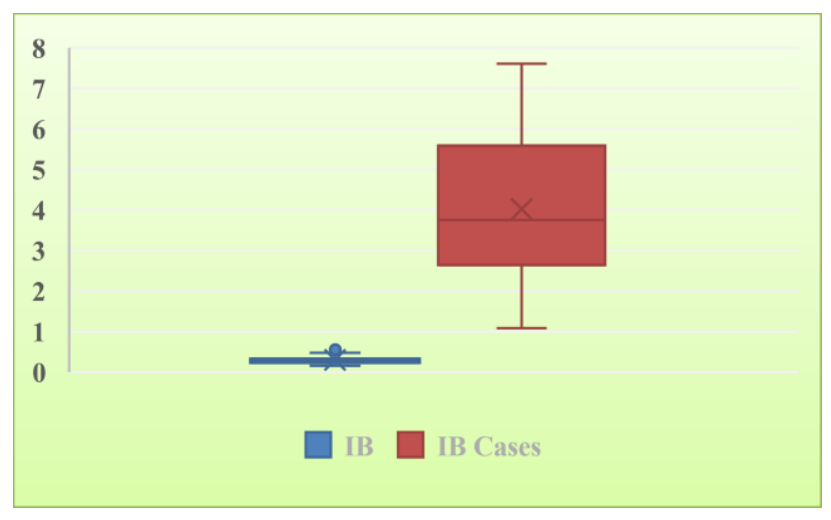

Figure 4: Box and Whisker plot for indirect bilirubin among control and cases.

This type of graph is used to show the shape of the distribution, its central value, and its variability. In a box and whisker plot, the ends of the box are the upper and lower quartiles, so the box spans the interquartile range.

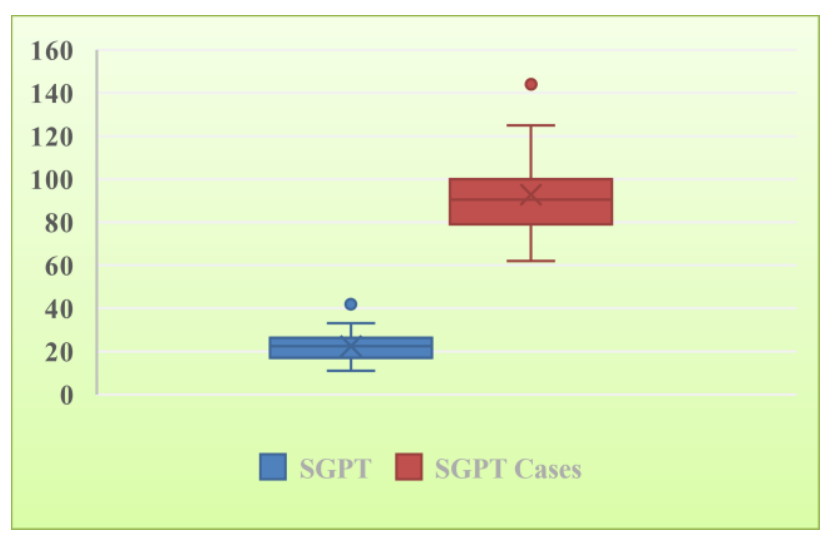

Figure 5: Box and Whisker plot for SGPT among control and cases. 


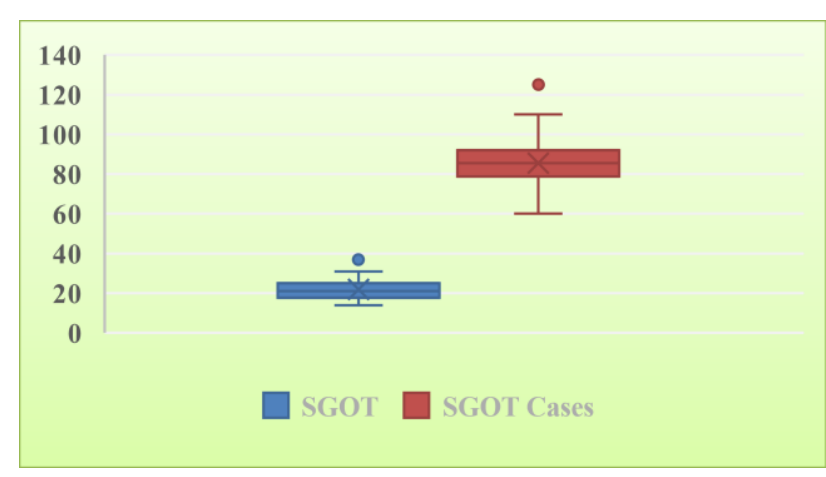

Figure 6: Box and Whisker plot for SGOT among control and cases.

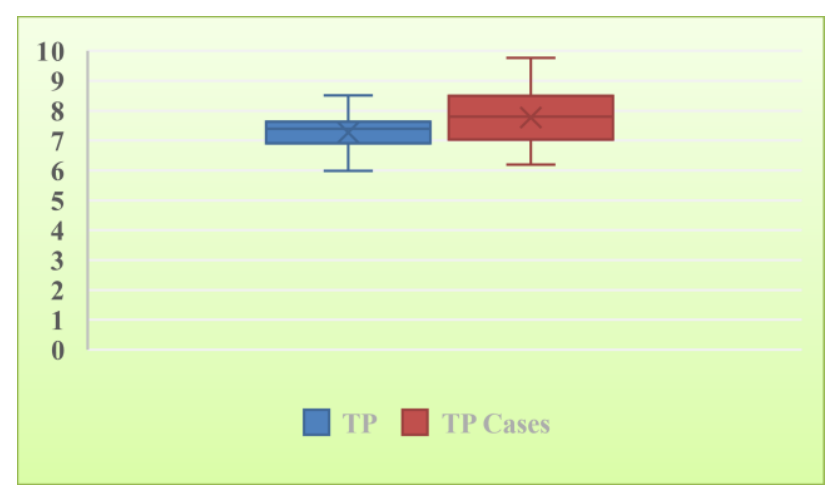

Figure 7: Box and Whisker plot for TP among control and cases.

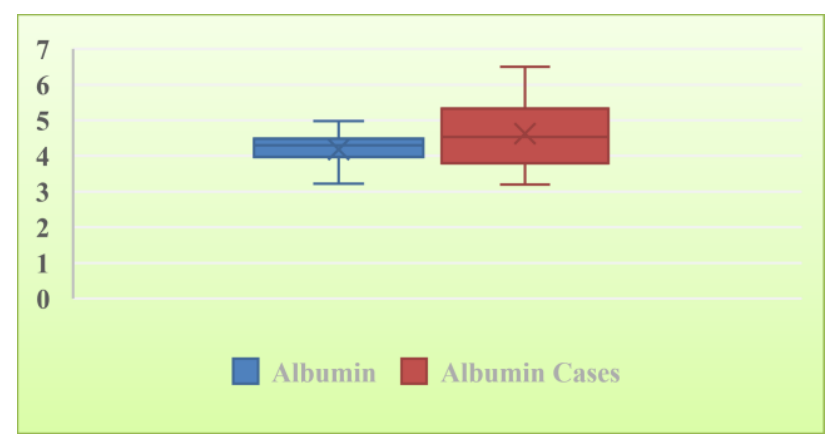

Figure 8: Box and Whisker plot for albumin among control and cases.

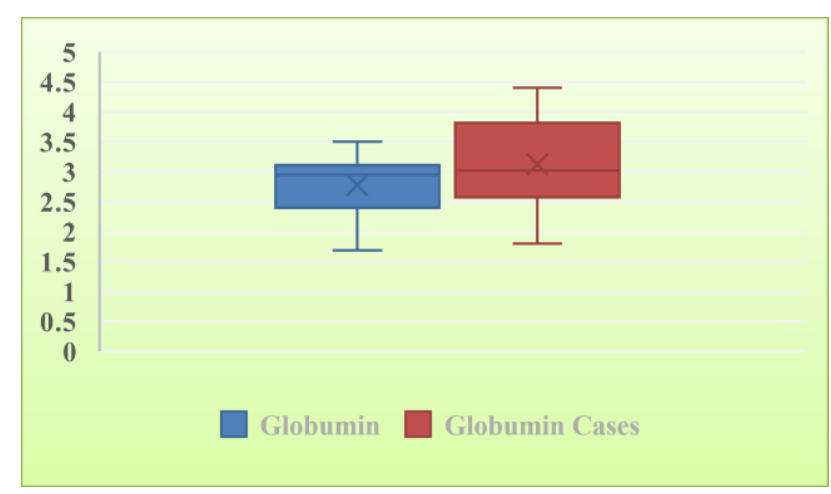

Figure 9: Box and Whisker plot for globumin among control and cases.

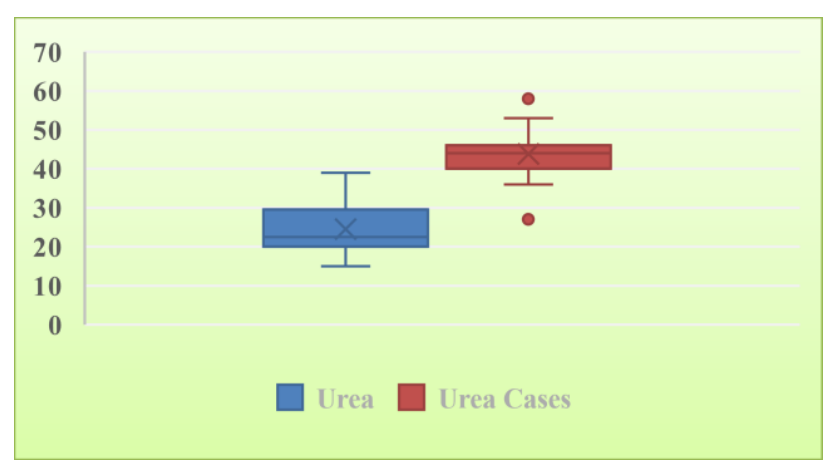

Figure 10: Box and Whisker plot for urea among control and cases.

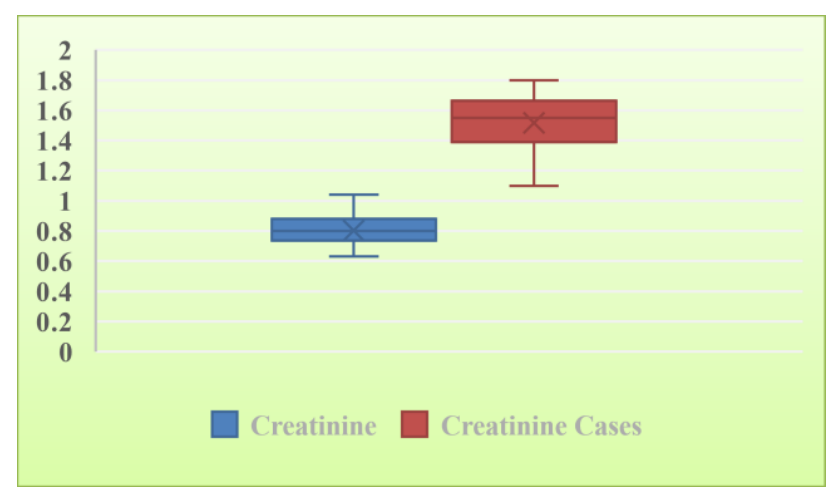

Figure 11: Box and Whisker plot for creatinine among control and cases.

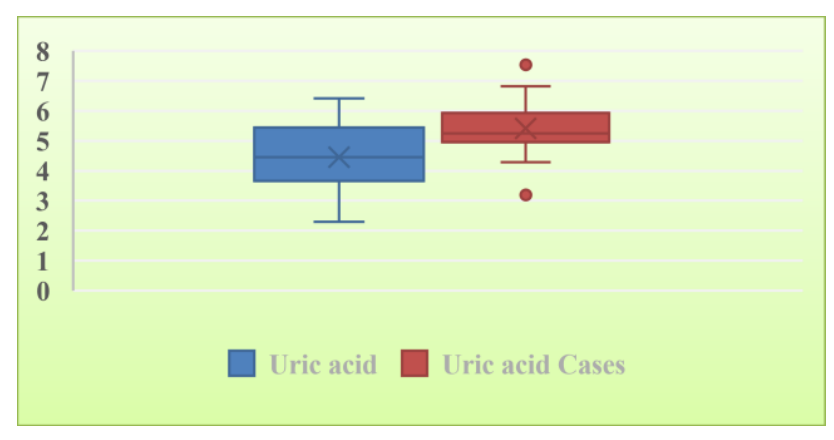

Figure 12: Box and Whisker plot for uric acid among control and cases.

\section{DISCUSSION}

Hypertensive disorders complicating pregnancies are common now a days and consists of both eclampsia and pre-eclampsia. Pre-eclampsia is a condition that develops in previously normotensive pregnant women after 20 weeks of gestation and is characterized by onset of hypertension and proteinuria. Pre-eclampsia can affect every maternal organ, predominantly the vascular, renal, hepatic, cerebral and coagulation system. . $^{5,10}$ Concentration of serum bilirubin in the present study was significantly higher $(\mathrm{P}<0.001)$ in patients of preeclampsia before delivery than the control group of same age and parity with normal blood pressure. Malvino et al showed that in HELLP syndrome serum bilirubin 
concentration was elevated from its normal value to about $>1.2 \mathrm{mg} / \mathrm{dl} .{ }^{11}$ Similarly Jaleel et al noted that there was a highly significant rise in serum bilirubin, lactate dehydrogenase and aspartate aminotransferase level in pre-eclamptic women compared to normotensive pregnant women. ${ }^{12}$ Serum ALT of pre-eclamptic women in the present study was significantly $(\mathrm{P}<0.001)$ elevated from their normotensive pregnant counterparts. Malvino et al observed that in pre-eclampsia the serum transaminase level was raise to $>10 \mathrm{U} / \mathrm{L}$ and that of ALT to $271 \pm 297 \mathrm{U} / \mathrm{L}{ }^{11}$

In the present study the mean serum AST level in preeclamptic cases was found significantly higher $(p<0.001)$ than the normotensive control group. Serum AST level in pre-eclampsia was also found more than $70 \mathrm{U} / \mathrm{L}$ by Malvino et al which rose up to $209 \pm 178 \mathrm{U} / \mathrm{L}$ in eclampsia. $^{11}$

Rath et al also noticed elevated level of ALT and AST in severe pre-eclampsia. ${ }^{13}$ Mechanism of raised liver enzymes hyper-vascularization and vasoconstriction of liver leading to cell injury, alteration of membrane permeability and damage to hepatocytes.

In present study the mean gestation age of pre-eclamptic patients was $35.4 \pm 4.18$ weeks. This is in agreement with Kim et al who noted that among the abnormal liver function tests in pregnancy $39.4 \%$ occurred between 30 and 40 gestational weeks while $29 \%$ occurred between 10 and 20 weeks and common causes were hyperemesis gravidarum followed by pre-eclampsia; viral hepatitis and HELLP syndrome. ${ }^{14}$

The limitation of present study is that the study subjects are less and should be done on a larger population.

\section{CONCLUSION}

In the present study serum levels of total bilirubin, SGOT, SGPT, total protein was significantly raised in the cases compared to controls. During pre-eclamptic pregnancy, the placenta is under oxidative stress with increased production of lipid peroxides along with antioxidants. Maternal circulating oxidized lipids may be the cause of endothelial cell destruction leading to liver cell injury. These results in abnormal liver function tests. More studies are required to substantiate present hypothesis.

Funding: No funding sources Conflict of interest: None declared

Ethical approval: The study was approved by the Institutional Ethics Committee

\section{REFERENCES}

1. Coppage KH, Sibai BM. Treatment of hypertensive complications in pregnancy. Curr Pharm Des. 2005;11(6):749-57.

2. Romero R, Vizoso J, Emamian M, Duffy T, Riely C, Halford $\mathrm{T}$, et al. Clinical significance of liver dysfunction in pregnancy-induced hypertension 1 . Am J Perinatol. 1988;5:146-51.

3. Verhaeghe J, Anthony J, Davery DA. Platelet count and liver function tests in protein uric and chronic hypertension in pregnancy. S Afr Med J. 1990;79:5904.

4. Bhowik DK, Akhtari R, Saha M, et al. Alteration of liver function in preeclampsia and eclampsia. CMOSH Med Coll J. 2013;12(3):9-10.

5. National High Blood Pressure Education Programme Working Group on High Pressure in pregnancy. Report of the National High Blood Pressure Education program. Working Group on High Blood Pressure in Pregnancy. Am J Obstet Gynecol. 2000;183(1):S1-22.

6. Davey DA, Mac Gillivray. The Classification and definition of the hypertensive disorders of pregnancy; Am J Obstet Gynecol. 1988;158:892-8.

7. Angel Gracia AL. Effect of pregnancy on pre-existing liver disease. Physiological changes during pregnancy. Ann Hepatol. 2000;5(3):184-6.

8. Burroughs AK. Pregnancy and liver disease. Forum (Genova). 1998;8(1):42-58.

9. ACOG Committee on Obstetric Practica. ACOG Practice bulletin. Diagnosis and management of preeclampsia and eclampsia. Obstet Gynecol. 2002;99(1):159-67.

10. Lopez-Jaramillo P, Casas JP, Serrano N. Preeclampsia from epidemiological observation to molecular mechanism. Broz J Med Biol Res. 2001;34(10):122735.

11. Malvino E, Munoz M, Ceccottic C, Janello G, Mc Loughlin D, Pawlak A, et al. Maternal morbidity and perinatal mortality in HELLP syndrome (Multicentric studies in intensive care units in Buenos Aires area). Medicina (B. Aires). 2005;65(1):17-23.

12. Jaleel A, Baseer A, Aamir S. Biochemical parameters for detection of hemolysis in pregnancy induced hypertensive woman. J Coll Physicians Surg Pak. 1999;9(1):41-2.

13. Rath W, Faridi A, Dudenhausen JW. HELLP Syndrome. J Perinat Med. 2000;28(4):249-60.

14. Kim JH, Kwon CI, Ko EH, Kim DY, Kim HY, Jung $\mathrm{SH}$, et al. Abnormal liver function tests in pregnancy. Korean J Gastroenterol. 2007;50(1):36-41.

Cite this article as: Lodhi R, Roy N. Liver function tests in patients of pre-eclampsia in Bhilai,

Chhattisgarh, India: a clinical study. Int J Reprod Contracept Obstet Gynecol 2018;7:5102-6. 